\title{
The Effect of Consumptive Lifestyle, Beauty Vlogger as a Group of Brand Trust References as a Mediation Variable on the Decision of Purchase of Korean Cosmetics (Innisfree) in Surabaya
}

\author{
Reizano Amri Rasyid ${ }^{1}$, Denis Fidita Karya ${ }^{2}$ \\ 1,2 S1 Management Program Study, Faculty of Economics and Business, University Of Nahdlatul Ulama Surabaya \\ Corresponding author. Email: reizano21@ @nusa.ac.id
}

\begin{abstract}
This study aims to examine the effect of consumptive lifestyle, beauty vlogger and brand trust on purchasing decisions on Innisfree Korea cosmetic products. This study uses primary data derived from questionnaire respondents using Innisfree products. The sample in this study amounted to 210 respondents. Using the non-probability sampling method used in analyzing data in this study using SmartPLS 3.0. Based on the results of the analysis and hypothesis testing can be obtained the results that consumptive lifestyle has a positive effect on purchasing decisions, but negatively affects brand trust. Beauty vlogger has a positive effect on purchasing decisions and negatively affects brand trust. Brand trust has a positive effect on purchasing decisions.
\end{abstract}

Keywords: Consumptive Lifestyle, Beauty Vlogger, Brand Trust, and Purchasing Decisions.

\section{INTRODUCTION}

The success of the globalization of South Korean culture can bring their local brand products known to many countries, including Indonesia. Korean cosmetic products are one of the products that attract the attention of many Indonesian women, especially in the younger generation.This study aims to examine the effect of consumptive lifestyle, beauty vlogger and brand trust on purchasing decisions on Innisfree Korea cosmetic products. This type of research is a method of nonprobability sampling method used in analyzing data in this study using SmartPLS 3.0. This research including descriptive analysis is used to provide an empirical description or description of the data collected in the study [1].

This study uses primary data derived from questionnaire respondents using Innisfree products. The sample in this study amounted to 210 respondents. The data that has been collected will then be processed by the data editing as the first stage of data processing. At this stage the data from observations, measurements and interviews were corrected. A lifestyle to consume excessive goods that are actually less necessary to achieve maximum satisfaction [2]. At this time, many teenagers are familiar with a more modern lifestyle. Sometimes they do not consider the needs and pleasures of buying a product, thus making it wasteful or known as consumptive behavior [3]. Vlogger is a person who makes a Vlog (Video blog) that contains post material in the form of video. This type of video usually displays a recording of a person's profile, daily activities carried out by that person, as well as experiences felt and so on [4].

Trust can be used to measure the scale of consumers' liking for brands. Brand trust is a sense of security that is owned by a consumer through interaction with the brand based on consumer perceptions that the brand can be trusted and responsible for the interests and welfare of consumers [5].Purchasing decision is an approach to 
solving problems in human activities to buy an item or service in fulfilling their wants and needs, which consists of the introduction of needs and wants, information seeking, evaluation of alternative purchasing, purchasing decisions, and behavior after purchase [6].

This study examines the influence of Korean cosmetics purchasing decisions on millennial generation in Surabaya. This research will only discuss the effect of consumptive lifestyle, beauty vlogger and brand trust on Korean cosmetics. In this study the theory is taken from the consumptive lifestyle theory, beauty vlogger, brand trust and purchasing decisions. This research will discuss (1) consumptive lifestyle influences purchasing decisions. (2) beauty vlogger influences purchasing decisions. (3) consumptive lifestyle influences brand trust. (4) beauty vlogger influences brand trust. (5) brand trust influences purchasing decisions.

\subsection{Related Work}

According to the generation type of assumptions, we divided the existed work into four categories.

\subsubsection{Consumptive Lifestyle}

Consumptive behavior is the human tendency to consume without limits, so it is not uncommon for humans to be more concerned with wants than their needs [7]. The desire of modern society to consume something that seems to have lost touch with real needs. Buying is no longer done because of a necessity, but just simply follows fashion, wants to try new products, and wants to gain social recognition. Consumptive behavior is an act of consuming products due to feelings of wanting to own an item or service, not based on needs but because of a desire to fulfill pleasure alone without being able to distinguish between needs, wants or requests [8]. This will have an impact on consuming something excessively so that it will behave consumptively. Then, from the desires that often arise will make a habit in a short period of time which makes the person excessive in shopping so that it becomes a person who has a consumptive lifestyle [9].

Based on the various descriptions above, it can be concluded that a consumptive lifestyle is a pleasure from the community which cannot distinguish between their needs and desires. This can cause consumers to consume products or buy products in excess of the purchasing decision process. Thus, the increasing number of products available will make people more selective and buy products where the product is not of their needs.

\subsubsection{Beauty Vlogger}

Beauty vloggeris someone who makes and uploads videos about beauty. Beauty here is defined as what is used related to skincare, makeup, or other beauty tools by vlogge [10]. So it can be concluded that a beauty vlogger is a person or group that makes a vlog aimed at recommending and reviewing beauty and the products used. The role of Beauty vlogger in providing information about products to suggest where to buy products both from online stores and counters in department stores. This can help find out more easily knowing the specifications of certain beauty products and can benchmark with other beauty products easily and quickly to find the best beauty products that will indirectly stimulate the viewer's buying interest in beauty products reviewed by a vlogger. Beauty vlogger will directly influence the purchase interest of a product because the main purpose of a beauty vlogger is to persuade and educate in real terms about a beauty product. The ability of a beauty vlogger as a beauty brand endorser in the video will increase consumer confidence in the product [11]. The success of a beauty vlogger in an effort to review and introduce a product depends also on the method applied in the process. The existence of a beauty vlogger will have an impact on the company where the company will benefit from their popularity. Beauty vloggers will also get benefits in the form of followers or followers and they will get a salary or wage from the content they make. So the beauty vlogger is an influencer to influence people to buy products similar to them.

\subsubsection{Brand Trust}

Trust can be used as a measurement scale for liking a brand, where a buyer's liking for a brand belongs to the fourth level of loyalty in the pyramid of brand loyalty. Brand trust as a feeling of security held by the consumer in his / her interaction with the brand, that it is based on the perceptions that the brand is reliable and responsible for the interests and welfare of the consumer [12]. Brand trust is a sense of security owned by a consumer through its interaction with a brand based on consumers' perceptions that the brand can be trusted and responsible for the interests and welfare of consumers.

Customer trust in the brand (brand trust) is defined as the customer's desire to rely on a brand with the risks faced because of expectations of the brand that will lead to positive results [14]. Trust when a group has confidence that the exchange partner has reliability and integrity [15]. Based on the opinion above, brand trust is defined as consumers' perceptions of trust and security towards a brand that appears voluntarily and assumes that the brand will meet their expectations or expectations. Although the brand releases a new product, consumers will buy and consumers already have expectations about the product. When consumers have a sense of brand trust, consumers may buy new products released by the brand.

\subsubsection{Buying Decision}

There are several steps taken by consumers in making the purchase decision process. These stages that will produce a decision to buy or not on a product. After buying a product the consumer will feel satisfied or dissatisfied with the product he bought. Purchase decisions that have been taken are a collection of a 
number of decision structure components [16]. Purchasing decision is an approach to solving problems in human activities to buy an item or service in meeting their wants and needs, which consists of the introduction of needs and desires, information search, evaluation of alternative purchases, purchasing decisions, and behavior after purchase. So that purchasing decisions are consumer activities to meet the needs and desires to consume products either through brand preferences or other alternatives.

\subsection{Our Contribution}

This research is expected to be used as an additional reference for subsequent researchers. The results of this study are expected to increase academic repertoire so that it is useful for the development of science. The usefulness of the research to be achieved, especially for local cosmetics companies, is that it can be used as information material and consideration for developing businesses in the face of foreign cosmetics competition and as a basis for decision making related to marketing strategies.

\subsection{Paper Structure}

This study examines the influence of Korean cosmetics purchasing decisions on millennial generation in Surabaya. This research will only discuss the effect of consumptive lifestyle, beauty vlogger and brand trust on Korean cosmetics. In this study the theory is taken from the consumptive lifestyle theory, beauty vlogger, brand trust and purchasing decisions. This research will discuss (1) consumptive lifestyle influences purchasing decisions. (2) beauty vlogger influences purchasing decisions. (3) consumptive lifestyle influences brand trust. (4) beauty vlogger influences brand trust. (5) brand trust influences purchasing decisions.

\section{BACKGROUND}

\subsection{Characteristic Respondents}

The study was conducted distributing questionnaires to 230 respondents who were processed as many as 210 respondents, using non random sampling. The results of the data in this study were obtained from a questionnaire distributed to respondents using Korea Innisfree cosmetic products.
Table 1. Characteristics of Respondents

\begin{tabular}{|c|c|c|c|}
\hline No & Characteristics & total & $\begin{array}{l}\text { Percentage } \\
(\%)\end{array}$ \\
\hline 1 & $\begin{array}{l}\text { Age: } \\
\text { a. } 17 \text { years }-20 \text { years } \\
\text { b. } 21 \text { years }-25 \text { years } \\
\text { total }\end{array}$ & $\begin{array}{l}100 \\
110 \\
\mathbf{2 1 0}\end{array}$ & $\begin{array}{l}47.62 \% \\
52.38 \% \\
\mathbf{1 0 0 \%}\end{array}$ \\
\hline 2 & $\begin{array}{l}\text { Income: } \\
\text { a. <Rp. } 750,000 \\
\text { b. Rp. } 750,000-\mathrm{Rp} . \\
\text { 1,500,000 } \\
\text { c. Rp. } 1,500,000 \\
\text { Rp. } \\
\text { 3,000,000 } \\
\text { d. Rp. } 3,000,000-\mathrm{Rp} \text {. } \\
\text { 5,000,000 } \\
\text { e. > Rp. } 5,000,000 \\
\text { total }\end{array}$ & $\begin{array}{l}60 \\
50 \\
40\end{array}$ & $\begin{array}{l}28.57 \% \\
23.81 \% \\
19.05 \% \\
14.28 \% \\
14.28 \% \\
100 \%\end{array}$ \\
\hline
\end{tabular}

Source: Primary data processed with SPSS 22, 2020

\subsection{Average Variant Extracted (AVE)}

In this study there are requirements to continue the research results to be processed. Mthe other method is to look at the average variant extracted (AVE) value for each indicator, the value must be $>0.5$ for a good model.

Table 2. Average Variant Extracted (AVE)

\begin{tabular}{|l|l|}
\hline Variable & $\begin{array}{l}\text { Average Variance Extracted } \\
\text { (AVE) }\end{array}$ \\
\hline $\begin{array}{l}\text { Consumptive } \\
\text { Lifestyle }\end{array}$ & 0.528 \\
\hline Beauty Vlogger & 1,000 \\
\hline Brand Trust & 0814 \\
\hline Buying decision & 0.621 \\
\hline
\end{tabular}

Based on the data presentation in table 3 above, it is known that the AVE value of consumptive lifestyle variables, beauty vlogger, brand trust and purchasing decisions $>0.5$. Thus it can be stated that each variable has a good discriminant validity.

\subsection{Hypothesis Testing}

Based on the data processing that has been done, the results can be used to answer the hypothesis in this study. Hypothesis testing in this study was conducted by looking at the T-Statistics value and the P-Values value. The research hypothesis can be accepted if the P-Values value

$<0.05$. The following are the results of hypothesis testing obtained in this study through the inner model: 
Table 3. T-Statistics and P-Values

\begin{tabular}{|l|c|c|c|}
\hline Variable & $\begin{array}{c}\text { T } \\
\text { Statist } \\
\text { i cs }\end{array}$ & $\begin{array}{c}\text { P } \\
\text { Valt s } \\
\text { ues }\end{array}$ & Resu \\
\hline $\begin{array}{l}\text { Beauty Vlogger -> } \\
\text { Brand Trust }\end{array}$ & 1,271 & $\begin{array}{c}0.20 \\
4\end{array}$ & Rejected \\
\hline $\begin{array}{l}\text { Beauty Vlogger - } \\
\text { >Buying decision }\end{array}$ & 2,237 & $\begin{array}{c}0.02 \\
6\end{array}$ & Received \\
\hline $\begin{array}{l}\text { Brand Trust ->Buying } \\
\text { decision }\end{array}$ & 3,070 & $\begin{array}{c}0.00 \\
2\end{array}$ & $\begin{array}{c}\text { Receiv } \\
\text { ed }\end{array}$ \\
\hline $\begin{array}{l}\text { Consumptive Lifestyle } \\
\text { Brand Trust }\end{array}$ & 1,588 & 0.04 & $\begin{array}{c}\text { Reject } \\
\text { ed }\end{array}$ \\
\hline $\begin{array}{l}\text { Consumptive Lifestyle } \\
\text { >Buying decision }\end{array}$ & 5,724 & 0,00 & Receiv \\
ed
\end{tabular}

Hypothesis 1 which states consumptive lifestyle has a positive effect on purchasing decisions. The calculation result of SmartPLS 3.0 shows that consumptive lifestyle has a significant negative effect on purchasing decisions with a T-statistics value of 5.724 and $\mathrm{P}$-values of 0.000 , meaning that the first hypothesis is accepted. Hypothesis 2 which states beauty vlogger has a positive effect on purchasing decisions. The calculation result of SmartPLS 3.0 shows that beauty vlogger has a significant positive effect on purchasing decisions with a T-statistics value of 2,237 and P-values of 0.026. That is, the second hypothesis is supported. Hypothesis 3 which states that consumptive lifestyle has a negative effect on brand trust. The calculation result of SmartPLS 3.0 shows that consumptive lifestyle has a negative effect on brand trust with a T-statistics value of

1.588 and P-values 0.113. That is, the third hypothesis is rejected. Hypothesis 4 which states that beauty vlogger has a negative effect on brand trust. The calculation result of SmartPLS 3.0 shows that beauty vlogger has a significant negative effect on brand trust with a $\mathrm{T}$ statistics value of

1.271 and P-values 0.204, meaning that the fourth hypothesis is rejected.

Hypothesis 5 which states brand trust has a positive effect on purchasing decisions. The calculation result of SmartPLS 3.0 shows that brand trust has a positive effect on purchasing decisions with a T-statistics value of 3.070 and P-values of 0 . Based on the results of hypothesis testing, it can be concluded that the influence of consumptive lifestyle on purchasing decisions on Innisfree Korea cosmetic products has a positive and significant effect. The results of this study indicate that lifestyle to consume excessive goods that are actually less necessary to achieve maximum satisfaction. The influence of beauty vlogger on purchasing decisions on Korean cosmetics Innisfree has a positive and significant effect. The influence of YouTube Beauty Vlogger on purchasing decisions for cosmetic products found that there was a significant influence of YouTube Beauty Vlogger on product purchasing decisions.

Promotion is an important aspect of marketing management and is often said to be an ongoing process. Promotion causes people who were not previously interested in buying a product to become interested and try the product so that consumers make a purchase. The influence of consumptive lifestyle on brand trust in Korea Innisfree cosmetic products has a negative and not significant effect. Consumptive behavior is the act of consuming products due to a feeling of wanting to own an item or service, not based on needs but because of a desire to fulfill pleasure alone without being able to distinguish between needs, wants or requests. The influence of brand trust on brand trust in Korea Innisfree cosmetic products has a negative and not significant effect. Beauty vlogger specializes in providing information about the world of cosmetics and beauty and uploading their information on social media platforms, YouTube [17].

Consumer confidence in a product can be due to the emergence of beauty vloggers who introduce Korean products. The large number of Korean products presented in the market makes consumers see the review of these products. They search on social media about the products they want to buy, so that it can affect consumers' trust in a product because too many products are present in the community. The influence of brand trust on purchasing decisions on Korea cosmetics Innisfree has a positive and significant effect. Customer trust in brands (brand trust) is the desire of customers to rely on a brand with the risks faced because expectations of the brand will cause a positive thing. So that purchasing decisions are consumer activities to meet the needs and desires to consume products either through brand preferences or other alternatives. Most consumers will choose the products they buy with products they trust.

\section{CONCLUSION}

Based on the results of research that has been done, it can be concluded:

1. Hypothesis 1 is proven, that consumptive lifestyle influences purchasing decisions. This can also be interpreted thatlifestyle that tends to be consumptive will increase consumer purchasing decisions. They will not be able to distinguish between their needs or desires. They tend to shop for their pleasure and as their social status

2. Hypothesis 2 is proven, namely beauty vlogger influences purchasing decisions. This can also be interpreted thatthe use of beauty vlogger is expected to provide a positive association with a product and brand. The association can simply appear in the form of a particular thought or image that is associated with a brand. 
3. Hypothesis 3 is not proven, namely consumptive lifestyle has no effect on brand trust. This can also be interpreted thatpeople tend to choose the preferred brand, with the current state of society tends to have a consumptive style. They are more choices with existing products. However, consumers who already believe in a product, they will buy these products even though the product they have has the latest output.

4. Hypothesis 4 is not proven, that is, beauty vlogger has no influence on purchasing decisions. This can also be interpreted thatThe large number of Korean products presented in the market because beauty vlogger introduced the product, made consumers see the product review. They search on social media about the products they will buy.

Hypothesis 5 is proven, that brand trust has no influence on purchasing decisions. This can also be interpreted thatpurchasing decisions are the activities of consumers to meet their needs and desires to consume products either through brand preferences or other alternatives. Most consumers will choose the products they buy with products they trust.

\section{ACKNOWLEDGMENT}

This work was supported by Research and Community Development Nahdlatul Ulama University of Surabaya and Management Faculty Nahdlatul Ulama University of Surabaya.

\section{REFERENCES}

[1] Ferdinan, A. (2006). Metode Penelitian Manajemen (Pedoman Penelitian Untuk Menulis Skripsi, Tesis dan Disertasi Ilmu Manajemen). Universitas Semarang, diakses dari http://universitassemarang.ac.id/

[2] Ramadhan, Achmad S. 2012. Hubungan Gaya Hidup Konsumtif Dengan Harga Diri Mahasiswa Fakultas Psikologi Universitas "X". Jurnal Ilmu Keperawatan, (online), Vol. 3 No. 3 (www.fik.ui.ac.id diakses 9 Oktober 2015).

[3] Wahyudi. (2013). Tinjauan Tentang Perilaku Konsumtif Remaja Pengunjung Mall Samarinda Central Plaza. EJournal Sosiologi, 1(4), 26-36.

[4] Media, L. 2009. Youtube \& Google Video; Membuat, Mengedit dan Upload Video. Yogyakarta: Penerbit MediaKom.

[5] Suryani dan Rosalina. 2019. Pengaruh Brand Image, Brand Trust, dan Kualitas Layanan terhadap Keputusan Pembelian Ulang dengan
Kepuasan Konsumen sebagai Variabel Moderating.

[6] Devi, Anastasia dkk. 2014. Pengaruh Citra Merek, Harga dan Gaya Hidup Terhadap Keputusan Pembelian Produk Imitasi (Studi Kasus Pembelian Tas Imitasi Louis Voitton Pada Mahasiswa Fakultas Ilmu Sosial dan Ilmu Politik Universitas Diponegoro), (online), Vol. 3 No. 5 (www.ejorunal.undip.ac.id diakses 12 Januari 2015).

[7] Haryani, I., \& Herwanto, J. (2015). Hubungan Konformitas dan Kontrol Diri Dengan Perilaku Konsumtif Terhadap Produk Kosmetik pada Mahasiswi, 5-11.

[8] Abdullah, W., Hartono. (2015). Partial Least Square (PLS). penerbit Andi. Yogyakarta.

[9] Utami, W. T. (2014). Hubungan antara Citra Tubuh dengan Perilaku Konsumtif Kosmetik Make Up Wajah pada Mahasiswi.

[10] Widodo \& Mawardi. 2017. Pengaruh Beauty Vlogger Terhadap Source Characteristics Serta Dampaknya Terhadap Purchase Intention. Jurnal Administrasi Bisnis (JAB), 47 (1) : 63-69.

[11] Ananda, A \& Wandebori, H. 2016. "The impact of drugstore makeup product reviews by beauty vlogger on youtube towards purchase intention undergraduate students in Indonesia"International Conference on Ethics of Business, Economics, and Social Science, 266268.

[12] Aaker, David A. 2008. Manajemen Ekuitas Merek: Memanfaatkan Nilai dari suatu Merek. Terjemahan oleh Aris Ananda. Cetakan Ketiga. Jakarta: Mitra Utama.

[13] Afzal, H., Khan, M. A., Rehman, K. ur, Ali, I., \& Wajahat, S. (2014). Consumer's Trust in the Brand: Can it be built through Brand Reputation, Brand Competence and Brand Predictability. International Business Research, 3(1).

[14] Mohammad Rizan, 2012, "Pengaruh Brand Image Dan Brand Trust Terhadap Brang Loyalty The Botol Sosro Survey Konsumen The Botol Sosro Di Food Court Itc Cempaka Mas Jakarta Timur”, Jurnal Riset Manajemen Indonesia vOl. 3, No. 1 hal. 6 . 